\title{
PROVENANCE OF SANDSTONE CLASTS FROM CONGLOMERATE OF THE PALEOCENE-EOCENE ORCA GROUP IN PRINCE WILLIAM SOUND, ALASKA
}

MOLLIE D. POPE, Union College

Research Advisors: John Garver, Cameron Davidson

\section{INTRODUCTION}

The thick flysch facies of the Cretaceous to Eocene Chugach-Prince William terrane (CPW) represents a thick accretionary complex that extends approximately $2200 \mathrm{~km}$ across southern Alaska, and in the central area is comprised mainly of the Valdez Group and the Orca Group (Fig. 1) (Garver and Davidson, 2015; Davidson and Garver, 2017). The Valdez Group is traditionally viewed as a Campanian to Maastrichtian turbidite deposit with mafic volcanic rocks that have experienced lower greenschist facies metamorphism (Dusel-Bacon, 1991; Gasser et al., 2012). The Orca Group is Paleocene to Eocene turbidite and volcanic deposit that, in most places, has undergone prehnitepumpellyite facies metamorphism (Dusel-Bacon, 1991; Wilson et al., 2012).

The relationship between the Valdez Group and the Orca Group is poorly understood (Moffit, 1954). A common hypothesis suggested long ago is that they are stratigraphically related and are a continuous sequence (Capps and Johnson, 1915). Given recent zircon dating, the Valdez Group appears to have maximum depositional ages (MDA) of 75-65 Ma and the deposition of the Orca Group is between 60-50 Ma (Davidson and Garver, 2017). In this case, deformation of the Valdez Group may have occurred 65-60 Ma, just before the deposition of the oldest Orca Group turbidites began. Thus, the youngest strata of the Valdez Group must be older than the oldest strata of the Orca Group. An alternative hypothesis is that the Orca Group formed in a different location and was translated to its current position along strike slip faults after the deformation of the Valdez Group (cf. Plafker et al., 1994). This idea would mean that the ages of the two groups may overlap in age, and the time of juxtaposition of the Orca Group to the Valdez Group is unknown but important. After the deposition of the bulk of the Orca Group was completed, the CPW experienced plutonism by the near-trench SanakBaranof Belt (SBB) and the Eshmay plutons (Cowan, 2003; Davidson and Garver, 2017).

If a pluton crosscuts two terranes then the age of that pluton is the minimum age that the two terranes were juxtaposed (Coney et al., 1980). The SBB plutons intruded the CPW from 63-47 Ma, with a distinct age progression from $63 \mathrm{Ma}$ to the west to 50-47 Ma to the east (Davidson and Garver, 2017). In Prince William Sound the CPW terrane is also intruded by the Eshmay Suite Plutons (ESP) around 37-41 Ma (Fig. 1) (Johnson, 2012; Davidson and Garver, 2012; Garcia et al., 2019). The Eshamy suite plutons could be explained by high heat flow that melted Orca Group sediments and these melts then mixed in with mantlederived basalts (Johnson, 2012). The ESP stitch the two terranes, as they occur on both sides of the Contact Fault System (Fig. 1) (Davidson and Garver, 2017).

A key link between the Orca and Valdez Groups may be conglomerates that occur in the Orca Group. There are five main localities of conglomerates in PWS, and some of the most significant exposures are in eastern and northern PWS. These conglomerates were described by Grant and Higgins (1910) as being near the bottom of the Orca Group stratigraphy, specifically at the basal unconformity. However, Capps and Johnson (1915) described the conglomerates as being at the top of the Orca Group, occurring after and interleaved with basaltic volcanic rocks (cf. Tysdal and 


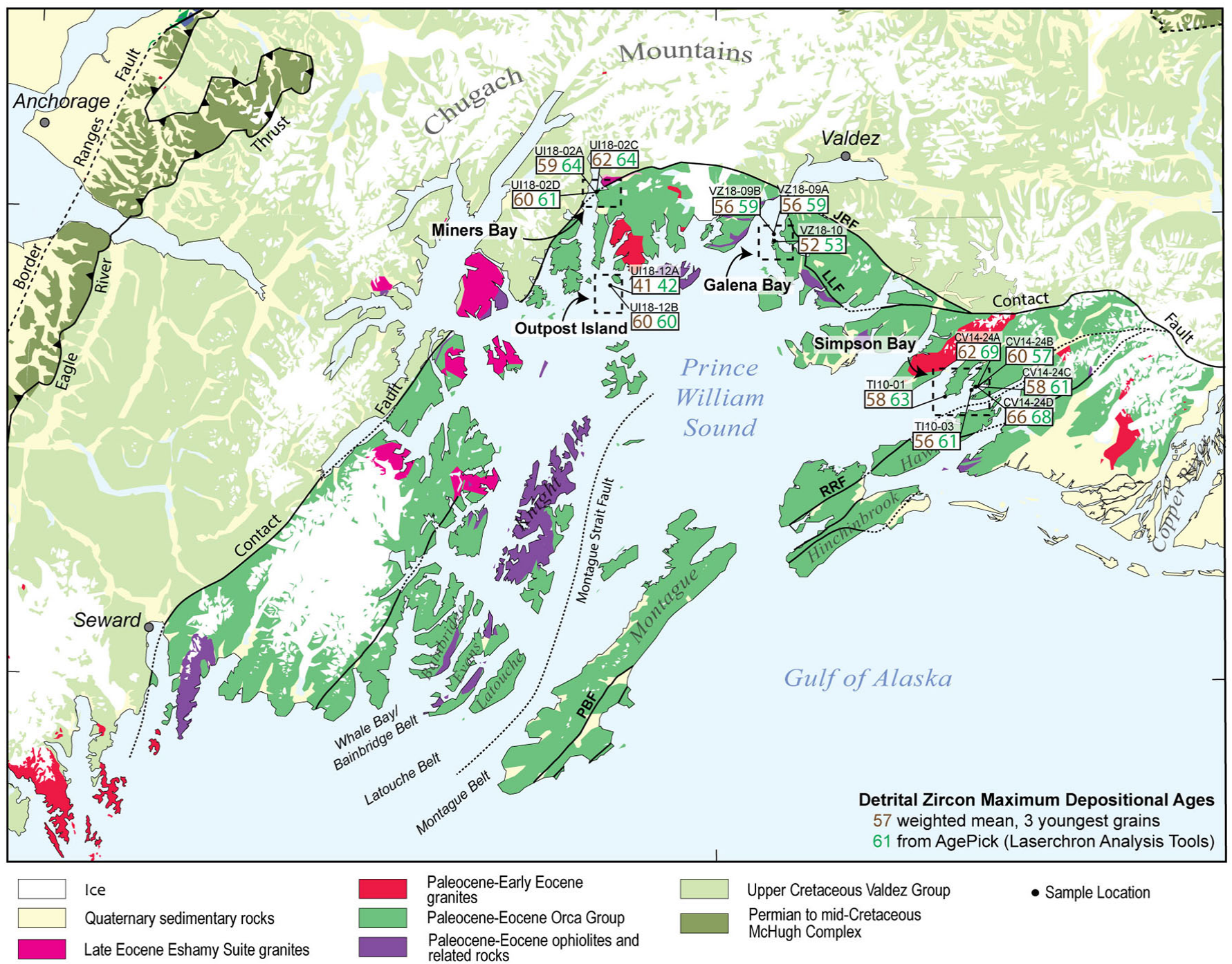

Figure 1. Map of study region in Prince William Sound. On this map the age of the the Sanak Baranof Belt and Eshamy Suite Plutons are indicated in red. Conglomerate matrix and clasts MDAs are all labeled at their sample site. The MDAs used in this paper are in brown, determined through the weighted mean on the youngest three grains (modified from Davidson and Garver 2017).

Case, 1979). If the Valdez Group is the source of the Orca Group conglomerate clasts, then the two terranes were adjacent at a time earlier than previously known (38-39 Ma) (Davidson and Garver, 2017).

Capps and Johnson (1915) proposed that the matrix of the conglomerates and the majority of the clasts were derived from the Valdez Group. They also suggest that a few clasts could be derived from the greenstones of the Orca Group. The provenance of the Orca Group conglomerates is important in our understanding of the relationship between the Valdez and Orca Groups as well as our overall understanding of the Cordilleran tectonics. This study will focus on understanding the Valdez Group and the Orca Group through the study of detrital zircons from sandstone clasts from the Orca Group Conglomerates and the host strata to those conglomerates.

\section{GEOLOGIC SETTING}

In the PWS area, the Valdez Group, which makes up about $90 \%$ of the Chugach terrane, is generally viewed as being Campanian-Maastrichtian (75-65 $\mathrm{Ma}$ ), deformed, metasedimentary graywacke, siltstone, and shale interbedded with meta-volcanic tholeiitic basalts and meta-intrusive rocks, that have undergone greenschist grade metamorphism (Dusel-Bacon, 1991; Plafker et al., 1994; Wilson and Hults, 2012). The Valdez Group is correlative with the Shumagin and Kodiak formations to the west, and parts of the Sitka Graywacke to the east, and together they extend for $2000 \mathrm{~km}$ along southern Alaska (Wilson and Hults, 2012). The Eagle River thrust bounds the flysch of the 

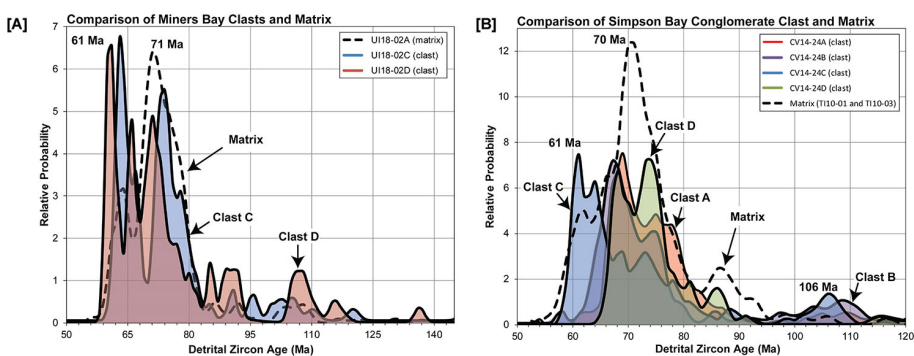

[c]
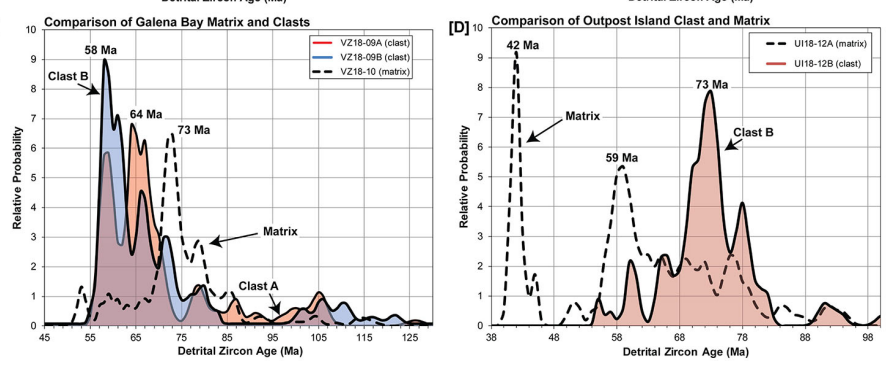

Figure 2. The probability density function (PDF) for each sample taken at the four conglomerate locations. [A] Probability density plot of Miners Bay conglomerate. The matrix UI18-02A (blacked dashed line) has a major population at $71 \mathrm{Ma}$, the clast UI18-02C (blue) has a major population at $63 \mathrm{Ma}$, and the clast UI18-02D (green) has a major population at $61 \mathrm{Ma}$. [B] PDF plot of the Simpson Bay conglomerate. The samples TI10-01 and TI10-03 (blacked dashed line) represent the matrix of the conglomerate. The clast has CV14-24C (blue) has a major population at $61 \mathrm{Ma}$ and the matrix has a major age population at 70Ma. [C] PDF plot of Galena Bay conglomerate clasts VZ18-09A (red) and VZ18-09B (blue) and matrix (black dashed line). The clasts age distribution has major population at 58 and $64 \mathrm{Ma}$. The matrix lacks these populations and instead has a large population at $73 \mathrm{Ma}$. [D] Probability density plot of Outpost Island conglomerate. The matrix UI18-12A (blacked dashed line) has a major population at $40 \mathrm{Ma}$ and $59 \mathrm{Ma}$, and the clast UI18-12B (red) has a major population at $73 \mathrm{Ma}$.

Chugach terrane to the north, separating it from the older mélange and the McHugh Complex and Potter Creek Assemblage (Amato et al., 2013; Davidson and Garver, 2017). The Border Ranges fault is the northern border of the Chugach terrane and it separates the terrane from the older more inland terranes of the Wrangellia composite terranes, and the southern boundary of the terrane is the Contact Fault and its equivalents (Davidson and Garver, 2017; Malik et al., 2019).

The Contact Fault system is thought to separate the Valdez Group to the North and the Orca Group to the south and it has an arcuate map trace across northern PWS (Malik et al., 2019). Across the fault, the Valdez Group and the Orca Group contain turbidites that have similar sandstone compositions, but overall the Valdez Group has undergone much more deformation (Plafker et al., 1994). In the east the Contact fault system is primarily composed of steeply north-dipping dextral strike-slip faults, with the system in the west being very difficult to define (Bol and Gibbons, 1992; Davidson and Garver, 2017). South of the main arc of the Contact fault is the Prince William terrane, composed of the Orca Group (Davidson and Garver, 2017).

The Paleocene to Eocene Orca Group is a thick sequence of turbidities and conglomerates with ultramafic to mafic volcanic sequences, that are metamorphosed to prehnite-pumpellyite facies (DuselBacon, 1991; Wilson and Hults, 2012). In PWS there are four locations of the Orca Group Conglomerates that were studied for this project: Miners Bay, Simpson Bay, Galena Bay, and Outpost Island (Fig. 1). Miners Bay is a poorly sorted, gravel to cobble $(5-30 \mathrm{~cm})$, clast-supported conglomerate with outsized clast $(40 \mathrm{~cm})$. The conglomerate contains primarily coarse-grained sandstone with some volcanic clasts. The Simpson Bay conglomerate is a clast supported, disorganized, sandstone-rich (80-90\%) conglomerate with minor light-gray, felsic volcanic rocks. The conglomerate at Galena Bay is a massive, clast supported, cobble conglomerate with outsize clasts, a sandstone matrix, and no obvious bedding or grading. This conglomerate contains approximately $65 \%$ sandstone (of which $60 \%$ are veined), $15 \%$ shale, $20 \%$ volcanics, and $<1 \%$ carbonate clasts. The conglomerate at Outpost Island is a cobble conglomerate with a coarse-grained sandstone matrix with approximately $80 \%$ of clast being fine-grained

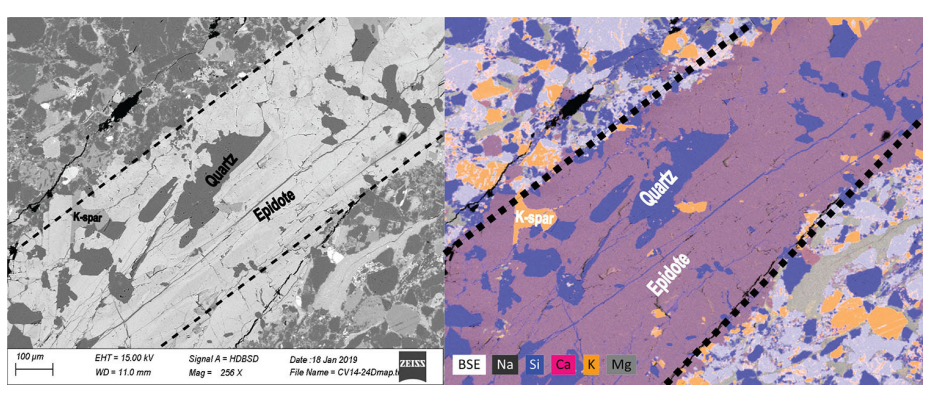

Figure 3. Mineral assemblage of veins from sample CV14-24D (MDA 66 Ma), a clast from Simpson Bay. In both images the vein boundary is defined with a black dashed line and an example of each mineral phase (Quartz, K-spar, and Epidote) is labeled. In the EDS image minerals that are orange correspond to K-rich feldspar, purple is indicative of quartz, and pink is indicative of epidote. Similar veins can be observed in Simpson Bay clast CV14-24A (MDA 62 Ma). 


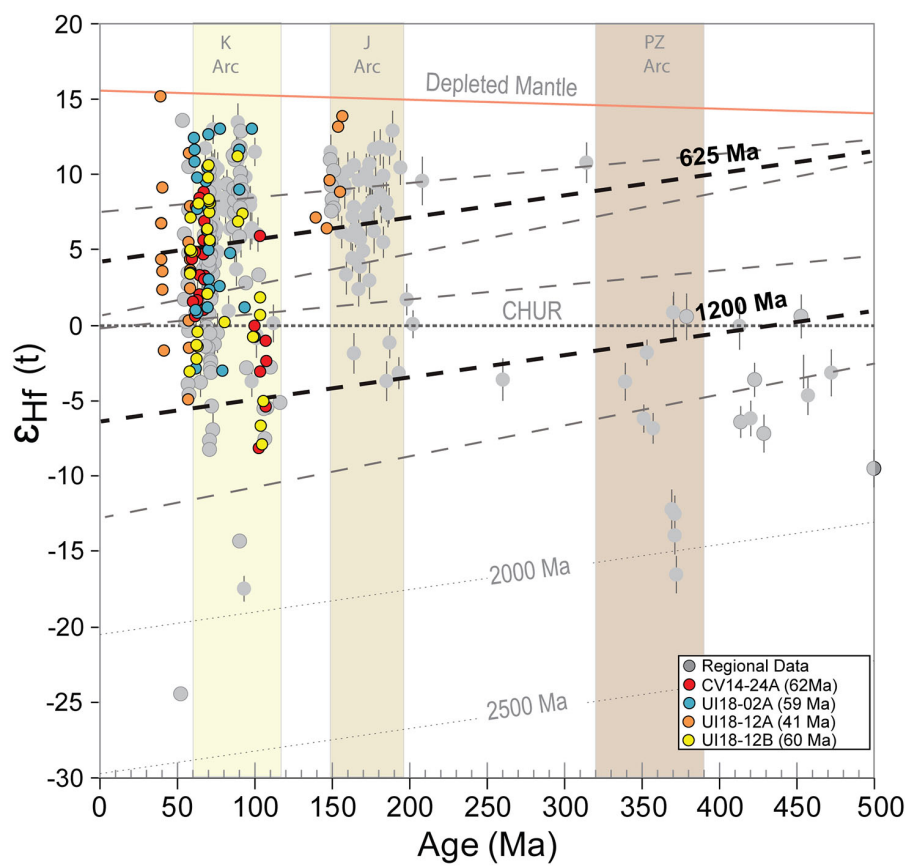

Figure 4. The $\varepsilon H f(t)$ for 67 new detrital zircon samples compared to other locations in southeastern Alaska (Shumagin Islands, Kodiak Island, and other parts of Prince William Sound). Extraction age of the zircons with a crystallization age of $70 \mathrm{Ma}$ is $625 \mathrm{Ma}$ and for those with a crystallization age of $\sim 100 \mathrm{Ma}$ it is $1200 \mathrm{Ma}$. This figure is adapted from Davidson and Garver (2017).

sandstone, $15-20 \%$ mudstone, and less than 5\% porphyry volcanic.

\section{METHODS}

Sandstone clasts and matrix were sampled from each of the four conglomerate locations in PWS. Whole rock samples were sent to GeoSep Services in Idaho or Carleton College in Minnesota to undergo a mineral separation process where detrital zircons were isolated. This process involves a large piece of the whole rock (2-4 kg) crushed to sand sized particles that are then separated by density, first on a water table and then using heavy liquids. Magnetic separation was then used to isolate zircons. $\mathrm{U} / \mathrm{Pb}$ geochronology and Hf isotope analysis was conducted on detrital zircons by laser ablation inductively coupled plasma mass spectrometry (LA-ICP-MS) at the University of Arizona LaserChron Center. The maximum depositional age (MDA) for each sample was determined by calculating the weighted mean of the three youngest zircon ages of each sample. Thin sections of sandstone clasts were imaged using a Zeiss EVO-MA15 scanning electron microscope (SEM) and mapped using QUANTX Electron Dispersive Spectroscopy (EDS) at Union College.

\section{RESULTS}

The conglomerate at Miner's Bay (UI18-02) is a poorly sorted, gravel to cobble $(5-30 \mathrm{~cm})$, clastsupported conglomerate with outsized clasts (up to $40 \mathrm{~cm}$ ). The conglomerate contains primarily coarsegrained sandstone with some volcanic clasts. The matrix of this sample (UI18-02A) yielded an MDA of $59.4 \pm 1.1 \mathrm{Ma}$, and the clast, UI18-02C and UI18$02 \mathrm{D}$, yielded MDAs of $61.6 \pm 1.1$ and $59.5 \pm 1.0 \mathrm{Ma}$ with major grain-age populations at 61 and $63 \mathrm{Ma}$, respectively.

The Simpson Bay conglomerate (CV14-24) near Cordova is a clast-supported, disorganized, sandstonerich (80-90\%) conglomerate with minor light-gray, felsic volcanic rocks. For this site, samples TI10-01 and TI10-3, from a location close to Simpson Bay, were used as matrix proxies (Izykowski, 2011), and were re-dated for this project. The clasts for this sample yielded MDAs of $61.5 \pm 1.0(\mathrm{CV} 14-24 \mathrm{~A})$, $60.3 \pm 1.3$ (CV14-24B), $58.4 \pm 0.8$ (CV14-24C), and $66.3 \pm 1.1 \mathrm{Ma}(\mathrm{CV} 14-24 \mathrm{D})$, with major populations at $74 \mathrm{Ma}, 69 \mathrm{Ma}, 68 \mathrm{Ma}$, and $61 \mathrm{Ma}$ (Fig. 2B). The matrix samples yielding a combined MDA of $57.4 \pm$ 1.2 Ma. Clasts CV14-24A and CV14-24D have clear veins with a mineral assemblage consisting of zoned epidote, quartz, and potassium-rich feldspar (Fig. 3).

The conglomerate at Galena Bay Island is a massive, clast-supported, conglomerate with a fine-grained sandstone matrix. Clasts consist of sandstone, shale, volcanic, and carbonate. At this location three sandstone clasts were collected (VZ18-09A, VZ1809B, and VZ18-09C), however, the matrix at this location was not easily sampled, so the matrix was collected from a nearby exposure on the mainland $\sim 750$ meters to the SSW (VZ18-10). An MDA of $56.4 \pm 1.0$ and $56.1 \pm 1.0$ was determined for VZ1809A and VZ18-09B with major age populations at $58 \mathrm{Ma}$ and $64 \mathrm{Ma}$, respectively (Fig. 2C). The nearby sandstone for this site (VZ18-10) has an MDA of 52.4 \pm 0.9 .

The conglomerate at Outpost Island is a cobble conglomerate with a coarse-grained sandstone matrix 

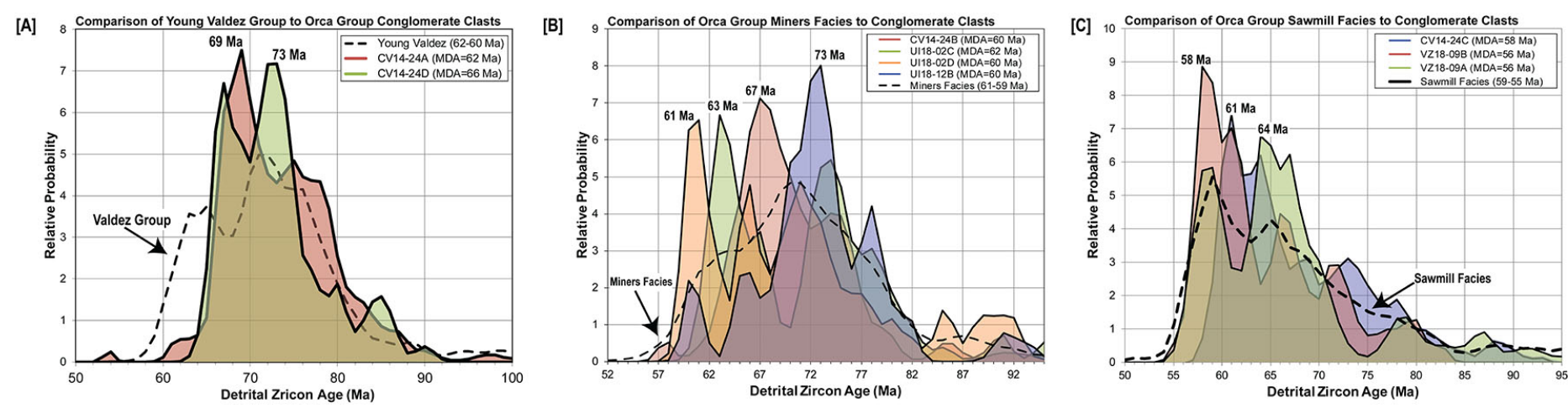

Figure 5. Probability density comparisons of sandstone conglomerate clasts to regional data. [A] Probability density plot of clasts CV14-24A (MDA 62 Ma) and CV14-24D (MDA 66 Ma) to the youngest Valdez Group samples (Gross Almonte et al., 2019). [B] Probability density plot of clasts CV14-24B (MDA 60 Ma), UI18-02C (MDA 62 Ma), UI18-02D (MDA 60 Ma), and UI18-12B (MDA 60 Ma) to the Miners Facies of the Orca Group (Fisher et al., 2019). [C] Probability density plot of clasts CV14-24C (MDA 58 Ma),VZ18-09A (MDA 56 Ma), and VZ18-09B (MDA 56 Ma) to the Sawmill Facies of the Orca Group (Fisher et al., 2019).

dominated by volcanic and less common sandstone clasts. In this regard this unit is distinct and different from other conglomerates because it has an abundance of volcanic clasts. The matrix of this conglomerate (UI18-12A) yielded an MDA of $40.9 \pm 0.7 \mathrm{Ma}$, and the clast (UI18-12B) yielded an age of $60.1 \pm 0.8 \mathrm{Ma}$ with a major grain age population of $73 \mathrm{Ma}$ (Fig. 2D).

The data for this project includes Hf isotope values for 193 detrital zircon throughout PWS. Hafnium isotope measurements when combined with zircon crystallization ages can be used to understand crustal evolution. Measured ${ }^{176} \mathrm{Hf} /{ }^{177} \mathrm{Hf}$ values are normalized to the chondritic uniform reservoir (CHUR) and reported in epsilon notation [eHf (t)] (Garver and Davidson, 2015). The $\varepsilon H f(t)$ values for this data set range from -8.3 to 15.1 with two exceptions that have values of -14.3 and -24.4 (Fig. 4).

\section{DISCUSSION}

The MDAs from this project provide insight into the position of the conglomerates in the stratigraphic column of the Orca Group ( 61 to $35 \mathrm{Ma}$ ) (Davidson and Garver, 2017). The MDAs of the Miners Bay and Simpson Bay conglomerates fall within the earliest time frame of the Orca Group (57 to $60 \mathrm{Ma}$ ), which would suggest that they sit at or near the base of the Orca Group (at $\sim 60$ Ma; Fisher et al., 2019). Recent dates of the Valdez Group indicate that it is as young as $\sim 61$ Ma meaning that there is no gap in age between the deposition of the Valdez Group and Orca Group (Fisher et al., 2019; Gross Almonte et al., 2019). The conglomerate at Galena Bay has an MDA of 52
$\mathrm{Ma}$, this falls between the middle and upper part of the Orca Group. The matrix of the conglomerate at Outpost Island (UI18-12A) has an MDA of $41 \mathrm{Ma}$, which corresponds to the youngest of the Orca Group and thus sits at the upper part of the stratigraphic column.

The ages of the Galena Bay and Outpost Island conglomerate correspond to the emplacement of plutons in this area. The nearby Sheep Bay Pluton of the SBB was emplaced at $~ 54 \mathrm{Ma}$, so the deposition of the Galena Bay conglomerate ( $\sim 52 \mathrm{Ma}$ ) occurred just after the emplacement of the pluton (Davidson and Garver, 2017). The Eshamy Suite plutons were emplaced from $\sim 38$ to $41 \mathrm{Ma}$, so The MDA of Outpost Island ( $\sim 41 \mathrm{Ma})$ overlaps with the emplacement of the Eshamy Suite plutons ( $\sim 38$ to $41 \mathrm{Ma}$ ) (Davidson and Garver, 2017). Thus, two conglomerates (Galena Bay and Outpost Island) appear to coincide, or nearly so, with pluton intrusion which raises the question of conglomerate sedimentation being a result of pluton emplacement, and perhaps disruption of the basin due to uplift and inflation.

Almost all conglomerate clasts dated yield ages that correspond to depositional ages associated with the Orca Group and probability density functions (PDF) that pass the K-S similarity test when compared to various Orca Group samples (Fig. 5) (Fisher et al., 2019). This result suggest that within a few million years of deposition the Orca Group was being uplifted and eroded. The veined sandstone clasts are mainly derived from the Orca Group cannibalization during this period. Two clasts from Simpson Bay, CV14- 
24A ( 62 Ma) and CV14-24D ( 66 Ma), have MDAs that can be tied to the depositional age of the Valdez Group (Figure 5A). These clasts also contain distinct veins composed of epidote, quartz, and potassium-rich feldspar, indicating that it has undergone greenschist grade metamorphism (Fig. 3). The Orca Group as a whole did not experience this high of a grade of metamorphism so it is likely that these two clasts have a Valdez affinity. Thus, this result means that the Orca Group must have been adjacent to the Valdez Group by $57 \mathrm{Ma}$.

The majority of $\varepsilon \mathrm{Hf}(\mathrm{t})$ data for clasts CV14-24A and UI18-12B are positive and corresponds to other regional data from the Shumagin Islands, Kodak Island, and other parts of Prince William Sound (Fig. 4). The $\varepsilon \mathrm{Hf}(\mathrm{t})$ values collected for zircons with crystallization ages of $\sim 70 \mathrm{Ma}$ and $\sim 100 \mathrm{Ma}$ suggest the existence of two distinct juvenile arcs with mantle extraction ages of $\sim 625 \mathrm{Ma}$ and $\sim 1200 \mathrm{Ma}$, respectively (Fig. 4). Overall, this suggest that during its formation, there was a large component of juvenile crust in the source region. The similarity between the clasts $\varepsilon \mathrm{Hf}(\mathrm{t})$ data to the regional data set (largely Valdez and equivalents) implies that the provenance of the two clasts are consistent with a local source, such as the Valdez Group.

\section{CONCLUSIONS}

The new $\mathrm{U} / \mathrm{Pb}$ detrital zircon data from the Orca Group Conglomerates shows that the MDAs of each conglomerate occur throughout the deposition of the Orca Group, so the conglomerates are located throughout the stratigraphic column. The MDAs and PDFs for the majority of the sandstone clasts correspond to the Orca Group, which implies that within a few years of its deposition the Orca Group was being uplifted and eroded. Two clasts from Simpson Bay have experienced greenschist metamorphism, and thus provide a link between the Orca Group and the Valdez Group. This means that the two groups must have been together by $57 \mathrm{Ma}$, much earlier than previously thought.

\section{ACKNOWLEDGEMENTS}

This material is based upon work supported by the Keck Geology Consortium and the National Science Foundation under Grant No. 1659322. Field work and analyses funded by NSF Grant "Collaborative Research: RUI: Translation and accretion of the Yakutat microplate and Prince William terrane, Alaska" NSF grants EAR-1728013 (Garver): NSF EAR 1727991 (Davidson), and NSF EAR 0619578 MRI (Garver and others at Union College). I want to thank the incredible field team Professor Tim Flood (St. Norbert College), Alysala Malik (Carleton College), Caitlin Noseworthy (St. Norbert College), Nick Gross Almonte (Carleton College), and Victor Garcia (University of Texas - Austin). I would also like to thank everyone at University of Arizona Laserchron Center an NSF supported multi-user facility ran by Mark Pecha and George Gehrels at the University of Arizona and that is funded by NSF-EAR Grant No. 1649254 for making the U/Pb and $\mathrm{Hf}$ analyses possible.

\section{REFERENCES}

Amato, J.M., Pavlis, T.L., Clift, P.D., Kochelek, E.J., Hecker, J.P., Worthman, C.M. and Day, E.M., 2013. Architecture of the Chugach accretionary complex as revealed by detrital zircon ages and lithologic variations: Evidence for Mesozoic subduction erosion in south-central Alaska. Bulletin, 125(11-12), pp.1891-1911.

Bol, A.J. and Gibbons, H., 1992. Tectonic implications of out-of-sequence faults in an accretionary prism, Prince William Sound, Alaska. Tectonics, 11(6), pp.1288-1300.

Capps, S.R., and Johnson, B.L., 1915, The Ellamar District, Alaska: U.S. Geological Survey Bulletin 605,pp, 100-125.

Coney, P.J., Jones, D.L. and Monger, J.W., 1980. Cordilleran suspect terranes. Nature, 288(5789), p.329.

Cowan, D.S., 2003. Revisiting the Baranof-Leech River hypothesis for early Tertiary coastwise transport of the Chugach-Prince William terrane. 
Earth and Planetary Science Letters, 213(3-4), pp.463-475.

Davidson, C. and Garver, J.I., 2017. Age and Origin of the Resurrection Ophiolite andAssociated Turbidites of the Chugach-Prince William Terrane, Kenai Peninsula, Alaska. The Journal of Geology ,125 (6), pp.681-700.

Dusel-Bacon, C., 1991. Metamorphic history of Alaska . US Geological Survey. Open-File Report 91-556.

Fisher, W.S., Pope, M.D., Malik, A.M., Garver, J.I., and Davidson, C.M., 2019. Zircon facies in the Paleocene-Eocene Orca Group indicate a provenance link to the Chugach terrane, Prince William Sound, Alaska. Geological Society of America Abstracts with Program, Cordilleran Section - 115th Annual Meeting, Portland Oregon. v. 51, n. 4. doi: 10.1130/ abs/2019CD-329384

Garcia, V.R. Jr, Stockli, D.F., Davidson, C.M, Garver, J.I., 2019. Crystallization ages and geochemistry of the Miners Bay and Cedar Bay plutons, Prince William Sound, Alaska. Geological Society of America Abstracts with Program, Cordilleran Section - 115th Annual Meeting, Portland Oregon. v. 51, n. 4. doi: 10.1130/ abs/2019CD-329495.

Garver, J.I., Davidson, C. and Northfield, M.N., 2012. Tectonic evolution of the Chugach-Prince William terrane in Prince William Sound and Kodiak Island, Alaska. In Proceedings from the 25th Keck Geology Consortium Undergraduate Research Symposium, Amherst (pp. 1-7).

Garver, J.I. and Davidson, C.M., 2015. Southwestern Laurentian zircons in upper Cretaceous flysch of the Chugach-Prince William terrane in Alaska. American Journal of Science , 315 (6), pp.537556.

Gasser, D., Rubatto, D., Bruand, E. and Stüwe, K., 2012. Large-scale, short-lived metamorphism deformation, and magmatism in the Chugach metamorphic complex, southern Alaska: A
SHRIMP U-Pb study of zircons. Bulletin, 124(56), pp.886-905.

Grant, U.S. and Higgins, D.F., 1910. Reconnaissance of the geology and mineral resources of Prince William Sound Alaska. Washington: Government Printing Office.

Gross Almonte, N., Fisher, W.S., Malik, A.M., Garver, J.I., and Davidson, C.M. 2019. Age and provenance of the Upper Cretaceous to Paleocene Valdez Group of the Chugach terrane from the Richardson Highway and northern Prince William Sound, Alaska. Geological Society of America Abstracts with Program, Cordilleran Section 115th Annual Meeting, Portland Oregon. v. 51, n. 4. Doi: 10.1130/abs/2019CD-329673.

Haeussler, P.J., Bradley, D.C., Wells, R.E. and Miller, M.L., 2003. Life and death of the Resurrection plate: Evidence for its existence and subduction in the northeastern Pacific in Paleocene-Eocene time. Geological Society of America Bulletin, 115(7), pp.867-880.

Izykowski, T.M., 2011, Detrital zircon fission track ages of the Paleocene Orca Group of Eastern Prince William Sound, near Cordova, Alaska [B.S. thesis]: Schenectady, Union College, 119 p.

Johnson, E., 2012, Origin of the Late Eocene Eshamy Suite Granitoids in Western Prince William Sound, Alaska: 25th Annual Keck Symposium: 2012, p. 33-39.

Malik, A.M., Fisher, W.S., Gross Almonte, N., Garver, J.I., Davidson, C.M., 2019. U-Pb dating of detrital zircon from turbidites of the Chugach and Prince William terrane in Prince William Sound, Alaska: Implications of the significance of the Contact fault system as a terrane boundary. Geological Society of America Abstracts with Program, Cordilleran Section - 115th Annual Meeting, Portland Oregon. v. 51, n. 4. doi: 10.1130/abs/2019CD-329396

Moffit, F.H., 1954, Geology of the Prince William Sound region, Alaska, IN Mineral resources of Alaska, 1951-53: U.S. Geological Survey 
Bulletin, 989-E, p. E225-E310, (incl. geologic map, scale 1:250,000)

Plafker, G., Keller, G., Nelson, S.W., Dumoulin, J.A. and Miller, M.L., 1985. Summary of data on the age of the Orca Group, Alaska: A section in The United States Geological Survey in Alaska: Accomplishments during 1984 (No. 967, pp. 7476). US Geological Survey.

Pope, M.D., Fisher, W.S., Malik, A.M. Garver, J.I., and Davidson, C.M., 2019. Provenance of sandstone clasts from conglomerate of the PaleoceneEocene Orca Group in Prince Willaim Sound, Alaska. Geological Society of America Abstracts with Program, Cordilleran Section - 115th Annual Meeting, Portland Oregon. v. 51, n. 4. Doi:

10.1130/abs/2019CD-329392

Tysdal, R.G. and Case, J.E., 1979. Geologic map of the Seward and Blying Sound quadrangles, Alaska (No. 1150).

Wilson, F.H., Hults, C.P., Swint-Iki, T.R. and Ryan, D.A., 2012. Geology of the Prince William Sound and Kenai Peninsula Region, Alaska: Including the Kenai, Seldovia, Seward, BlyingSound, Cordova, and Middleton Island 1: 250,000-scale Quadrangles. US Geological Survey. 